This item was submitted to Loughborough's Research Repository by the author.

Items in Figshare are protected by copyright, with all rights reserved, unless otherwise indicated.

\title{
The translation of cell-based therapies: clinical landscape and manufacturing challenges
}

PLEASE CITE THE PUBLISHED VERSION

http://dx.doi.org/10.2217/RME.14.73

PUBLISHER

Future Medicine Ltd / @ The Authors

VERSION

VoR (Version of Record)

\section{PUBLISHER STATEMENT}

This work is made available according to the conditions of the Creative Commons Attribution 3.0 Unported (CC BY 3.0) licence. Full details of this licence are available at: http://creativecommons.org/licenses/by/3.0/

\section{LICENCE}

CC BY 3.0

\section{REPOSITORY RECORD}

Heathman, Thomas R.J., Alvin W. Nienow, Mark J.S. McCall, Karen Coopman, Bo Kara, and Christopher J. Hewitt. 2015. "The Translation of Cell-based Therapies: Clinical Landscape and Manufacturing Challenges". figshare. https://hdl.handle.net/2134/16781. 


\title{
(2) Regenerative Medicine
}

\section{The translation of cell-based therapies: clinical landscape and manufacturing challenges}

\begin{abstract}
Cell-based therapies have the potential to make a large contribution toward currently unmet patient need and thus effective manufacture of these products is essential. Many challenges must be overcome before this can become a reality and a better definition of the manufacturing requirements for cell-based products must be obtained. The aim of this study is to inform industry and academia of current cell-based therapy clinical development and to identify gaps in their manufacturing requirements. A total of 1342 active cell-based therapy clinical trials have been identified and characterized based on cell type, target indication and trial phase. Multiple technologies have been assessed for the manufacture of these cell types in order to facilitate product translation and future process development.
\end{abstract}

Keywords: bioreactor $\bullet$ cell-based therapy $\bullet$ clinical trials $\bullet$ manufacture $\bullet$ MSC

- regenerative medicine $\bullet$ stem cell $\bullet$ translation

Regenerative medicine offers a transformative approach to healthcare, with the potential to not only treat, but cure disease. The therapeutic application of cells, or cell-based therapy, forms a fundamental part of this landscape and already has global revenues of over US $\$ 1$ billion [1]. With an everincreasing number of cell-based therapies in the pipeline this industry, if properly developed, has the potential to provide significant health and wealth benefits throughout the world.

The use of live cell-based therapies in medicine is not a new concept. The first successful allogeneic human hematopoietic stem cell transplant took place in 1968 [2] and is now a routine clinical procedure for bone marrow regeneration. The true value of stem cell-based therapies was not explored until some two decades later when the therapeutically relevant cells were considered for the regeneration of skeletal tissue [3] and later for broader therapeutic utility [4]. This led to the commercial venture into cellular therapy by Osiris Therapeutics (NASDAQ:OSIR), who have since received market approval in
Canada and New Zealand for Prochymal ${ }^{\mathrm{TM}}$, a mesenchymal stem cell (MSC) therapy for juvenile graft versus host disease.

Since the turn of the millennium there has been a steady increase in the number of cell-based therapy clinical trials, with an increasing spread of phases and number of target indications [5]. This increased diversity of target clinical indications has been largely driven by growing evidence of the trophic effects of infused cells, whereby the putative mechanism of action is by secretion of proteins and paracrine factors rather than terminal engraftment [6]. Alongside adult stem cells, pluripotent stem cells have attracted significant interest for cell-based therapy applications due to their high proliferative potential and ability to form any tissue in the body. Both embryonic stem cell and induced pluripotent stem cell-derived products are currently entering clinical development [7] but face many technical and ethical hurdles particularly around product safety [8].

Clinical activity in cell-based therapies is clearly converging upon a critical mass,
Thomas RJ Heathman', Alvin W Nienow ${ }^{1,2}$, Mark J McCall', Karen Coopman', Bo Kara ${ }^{3}$ \& Christopher J Hewitt*,1,4 ${ }^{1}$ Centre for Biological Engineering, Loughborough University, Leicestershire, LE11 3TU, UK

${ }^{2}$ Centre for Bioprocess Engineering, University of Birmingham, Birmingham, B15 2TT, UK

${ }^{3}$ FUJIFILM Diosynth Biotechnologies, Billingham, TS23 1LH, UK

${ }^{4}$ School of Life \& Health Sciences,

Aston University, Aston Triangle, Birmingham, B4 7ET, UK

*Author for correspondence:

Tel.: +44 1509222506

c.j.hewitt@lboro.ac.uk 
with over 300,000 patients treated with regulatoryapproved products since 1997 [9]. This does mean, however, that patient expectations are increasing and must be managed delicately to avoid a second wave of disillusionment in the sector, following the drop in commercial activity in the early 2000s [10]. In conjunction with this, great emphasis must be placed on patient safety by avoiding the exploitation of patients engaged in 'stem cell tourism' and the off-label or unlicensed use of stem cell-based therapies [11-13]. This is all part of a wider regulatory balance that on one hand ensures patient safety and on the other hand does not prevent much needed treatments reaching the clinic.

For the majority of clinical indications, the transplantation of primary donor cells may not be sufficient to meet the clinical need and the expansion of cells in culture will be required to address the shortage of therapeutically active cells available in the body. To ensure that these cell-based therapies can meet the needs of the patient, cells must be produced in sufficient numbers, with reproducible quality and at relatively low cost. For this to happen, suitable scalable manufacturing processes must be developed either before or during the clinical assessment phase, with the final optimal process used to produce batches for Phase III clinical studies typically carried forward to commercial production. The aim of these manufacturing processes is to significantly increase cell numbers without negatively affecting the therapeutic potential of the cell, which is known to deteriorate with time in culture [14]. It is possible that the manufacturing lot size required to meet this need will be in the order of trillions of cells, though this is dependent on the dose requirements per patient and market size of each indication [15]. Current manual planar culture technology is not sufficient to meet this requirement and new manufacturing methods must be developed to drive down the cost of goods to produce cost effective therapies and achieve product reimbursement.

There are currently many challenges facing the cellbased therapy industry particularly in the regulated manufacture of these products under GMP [16]. Conventional bioprocesses use cells to produce therapeutic agents, which can then be isolated and purified without the need to recover the cell. For the manufacture of cell-based therapies, retention of cell function and quality is of primary importance in order to preserve product efficacy [17]. This consideration is particularly pertinent, considering that a number of these cell types are adherent, meaning that they must be detached or harvested from a culture substrate, prior to downstream processing. To quantify this, effective manufacture is reliant on measuring these critical-to-quality attributes and establishing the allowable deviation of these product characteristics from a predetermined set point. The use of potency assays can provide a batch release test that validates whether the cell product is consistent, stable and of sufficient quality for therapeutic use, as well as providing a comparability metric to validate process changes [18]. Stringent safety assays must also be considered for cell-based therapies as many current processes use animal-derived products during culture, which could lead to pathogen transfer or immune complications once infused into the recipient [19]. Additionally, the use of pluripotent stem cells brings a new set of safety challenges within downstream purification, ensuring that the unlimited growth potential of these cells is not transferred to the patient [20]. The requirement for high levels of process and product characterization will result in significant direct costs in all process stages, from establishment of a master cell bank (for allogeneic products), to final product testing.

Cell-based therapies are complex biological products that are sensitive to their environment and display intrinsic variability within a tightly regulated industry. Variation in the product can come from two sources: process input material and process conditions [21]. For allogeneic therapies, where cells from one patient can be given to many patients, this input variability can be reduced by careful selection of comparable input material to the process. Alongside this, the variability in process conditions can be managed in part by automating the manufacturing process allowing for increased control and process capability [22-25]. This allogeneic or 'off-the-shelf' business model for cell-based therapies is far more akin to current biopharmaceuticals [26], where the product maintains long-term stability.

Conversely, autologous cell-based therapies, where cells are taken from a patient and returned to the same patient, represents a different manufacturing challenge as patient populations must be stratified to control this input variation. Issues surrounding the quality test burden and logistics of personalized (services based) medicine add to the complexity for large scale production and delivery of a cost effective autologous cell-based therapy [27]. Delivery of autologous cellbased products can be complex due to the short term preservation methods used for transport and delivery, for example the shelf life of Provenge, an autologous peripheral blood mononuclear cell-based therapy suspended in Lactated Ringer's Injection solution is only $18 \mathrm{~h}$ at $2-8^{\circ} \mathrm{C}$ [28]. Several allogeneic therapies in development are also shipped to clinical delivery sites in a noncryopreserved format. This results in the need to maintain a constant level of production, even when clinical demand may vary greatly, as noncryopreserved products typically have a shelf life on the order of 
days and significant product wastage can occur. This increases overall product cost and requires larger batch sizes to be produced. Considering the range of potential cell-based therapies it is clear that multiple manufacturing models must be evaluated in order to fill the need of both universal (scale up) and personalized (scale out) therapies and control the associated biological variation to achieve a consistent product.

Given the diversity of cell types, disease indications and delivery pathways it is unlikely that there will be a 'one-size-fits-all' manufacturing platform for cellbased therapies and therefore careful consideration must be given to process selection for commercial production during process definition, development and optimization, prior to clinical development. This study provides a snapshot of current cell-based therapy clinical trials by cell type, target clinical indication and trial phase and a comparative assessment of the process technology available to manufacture these cell-based therapies. The aim is twofold, firstly to inform industry and academia of current clinical activity involving their cell type and secondly to identify the challenges associated with the manufacture of these cell-based therapies. This analysis will provide a comparison tool for manufacturing technology and facilitate the development clinical indication specific quality assays by providing an overview of the current target clinical indications for cell-based therapies.

\section{Methodology}

To initiate this study, we searched for the term 'cell' on the ClinicalTrials.gov database [29] to include all clinical trials involving the use of cells up to January 1 , 2014. This produced 29,467 results, which were further sorted on the database to show only open trials reducing the number to 9700 which were extracted for analysis, providing an overview of the current cell-based therapy clinical trials landscape.

As this study is evaluating cell-based therapy clinical trials, the following British Standard Institute definition was used to classify these as a 'therapy in which cells are administered to the body to the benefit of the recipient' [30]. This excluded:

- Trials where the application of cell was not the main therapeutic goal of the study (i.e., studying the effect of a drug infused as part of a cell-based therapy);

- Trials that were observational (i.e., no direct application of cells to the patient);

- Duplicate trials (i.e., the same trial taking place in more than one country).
The 9700 trials were sorted manually one at a time by one individual to identify the true cell-based therapies using the definition above and the listed exclusion criteria. This action left a database of 1342 cell-based therapy clinical trials that were checked to ensure the major industry clinical trials had been encompassed and further categorized as detailed below.

\section{Cell type}

Each of the 1342 clinical trials was assigned a cell type based on the clinical trial listing and the cell used for therapeutic benefit but where no cell type was indicated, the cell type was listed as unknown. Where a clinical trial was assessing a combination of more than one cell type, both cell types were included in the study.

\section{Cell group}

The cell types in use for the clinical trials have been divided into multiple groups namely, hematopoietic cells $\left(\mathrm{CD} 34^{+}\right.$, mononuclear cells and whole marrow), MSCs, lymphocytes, dendritic cells, hepatocytes, endothelial cells, fibroblasts, myocytes, epithelial cells, islet cells, chondrocytes, renal cells, embryonic stem cells and other cells. The purpose of these groups is to show the spread of cell types in current active cell-based therapy clinical trials.

\section{Clinical indication}

Categorized based on clinical speciality and disease mechanism of action or where an indication falls into more than one category, by the greatest need. An example of this is stroke, which is a vascular disease that manifests as a neurological disorder and therefore is categorized in neurology as this is where the cell-based therapy treatment would be targeted.

\section{Trial phase}

The clinical trial phase was taken from ClinicalTrials. gov and divided into Phases I, II, III and IV. Where trials were in the transition between phases, only the completed phase was used (i.e., a listing of Phase I/II would be classified as Phase I).

This process yielded a thorough database of categorized cell-based therapy clinical trials that are currently open as of January 1, 2014. Although this provides a comprehensive database of cell-based therapy clinical trials on ClinicalTrials.gov, it does have a limitation. ClinicalTrials.gov was initiated as a result of the US FDA Modernization Act of 1997 as a registry of clinical trial information for federally and privately funded trials conducted under investigational new drug applications (later expanded under FDA Amendments Act of 2007). This means that clinical trials in the USA 
must be registered on ClinicalTrials.gov but clinical trials initiated in other countries are only included on a voluntary basis. Therefore, this method does not include all cell-based therapy clinical trials, just those registered through the National Institutes of Health. Limitations of this database have been previously discussed [31]. The methodology presented here will, however, contain the vast majority of cell-based therapy clinical trials and certainly a large enough sample to draw meaningful conclusions.

\section{Results}

\section{Clinical trial landscape for cell-based therapy}

Our search of the clinical trial database yielded a total of 1342 active clinical trials that were judged to be true cell-based therapies from the British Standard Institute definition as of January 1, 2014. The vast majority of these cell-based therapies are using hematopoietic cells $(\mathrm{n}=444)$, MSCs $(\mathrm{n}=382)$, lymphocytes $(\mathrm{n}=253)$ and dendritic cells $(n=91)$ (Figure 1). The use of tissue specific cells is less prevalent, representing 114 of current cell-based therapy activity with a mixture of cell types such as chondrocytes $(n=12)$, endothelial cells $(n=15)$, fibroblasts $(n=14)$, hepatocytes $(n=16)$, islet cells $(n=13)$ and neural cells $(n=13)$. Figure 2 shows the diversity of cell isolation sources represented from hematopoietic and MSC trials. The rapid increase in MSC activity is clear, with 382 clinical trials in progress from a number of isolation sources most notably 237 of which are from the bone marrow, 61 from umbilical cord and 59 from adipose tissue. The use of pluripotent stem cell-derived products is rare, though there are six clinical trials involving embryonic stem cells. Interestingly, all six involve differentiation into retinal pigment epithelium cells and are initiated by industry: CHA Bio \& Diostech in Korea (two), Advanced Cell Technology (three) and Pfizer in the UK (in collaboration with University College London).

\section{Disease indications targeted by cell-based therapy clinical trials}

It is clear that the most common target for cell-based therapy clinical trials is oncology, which represents $46 \%$ of all cell-based therapy clinical trials identified (Figure 1), due to the use of traditional blood cell and immune cell-based therapies for the treatment of various cancers. Aside from these traditional cell-based therapies, cardiology is the second largest clinical target with 88 clinical trials (Figure 1), 51 of which are using MSCs (Figure 3). Immunological disorders remain a key target for cell-based therapies (Figure 4) with disorders such as graft versus host disease $(n=33)$, immune modulation following transplantation $(\mathrm{n}=17)$ and Crohn's disease $(n=16)$, as well as rheumatic disorders osteoarthritis $(\mathrm{n}=15)$, lupus erythematosus $(\mathrm{n}=9)$ and rheumatoid arthritis $(n=6)$ currently in Phase I
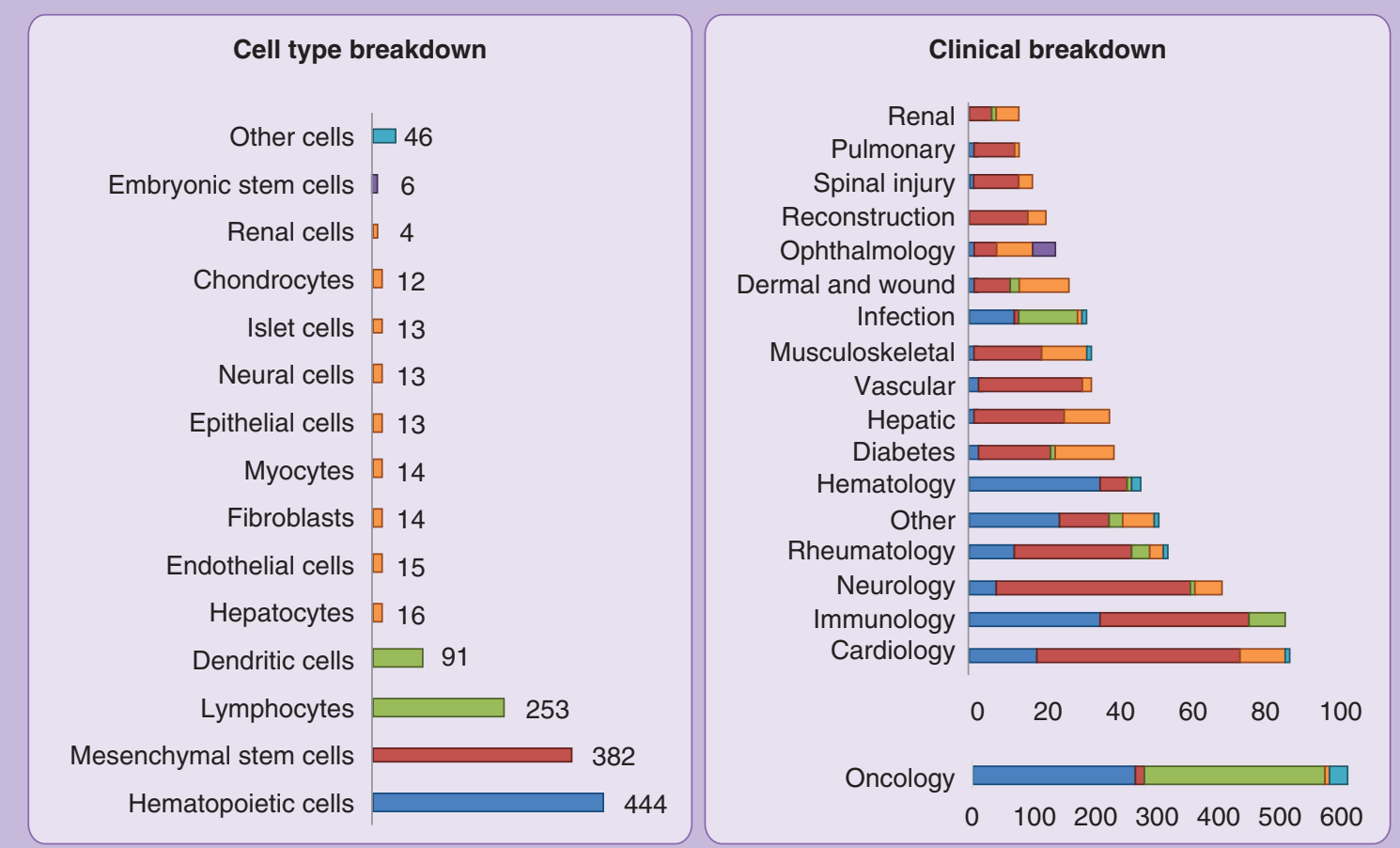

Figure 1. Number of active clinical trials by cell type and target clinical indication. Displaying broader cell type categories of hematopoietic (blue), mesenchymal stem cells (red), immune cells (green), tissue-specific cells (orange), embryonic stem cells (purple) and other (aqua). 

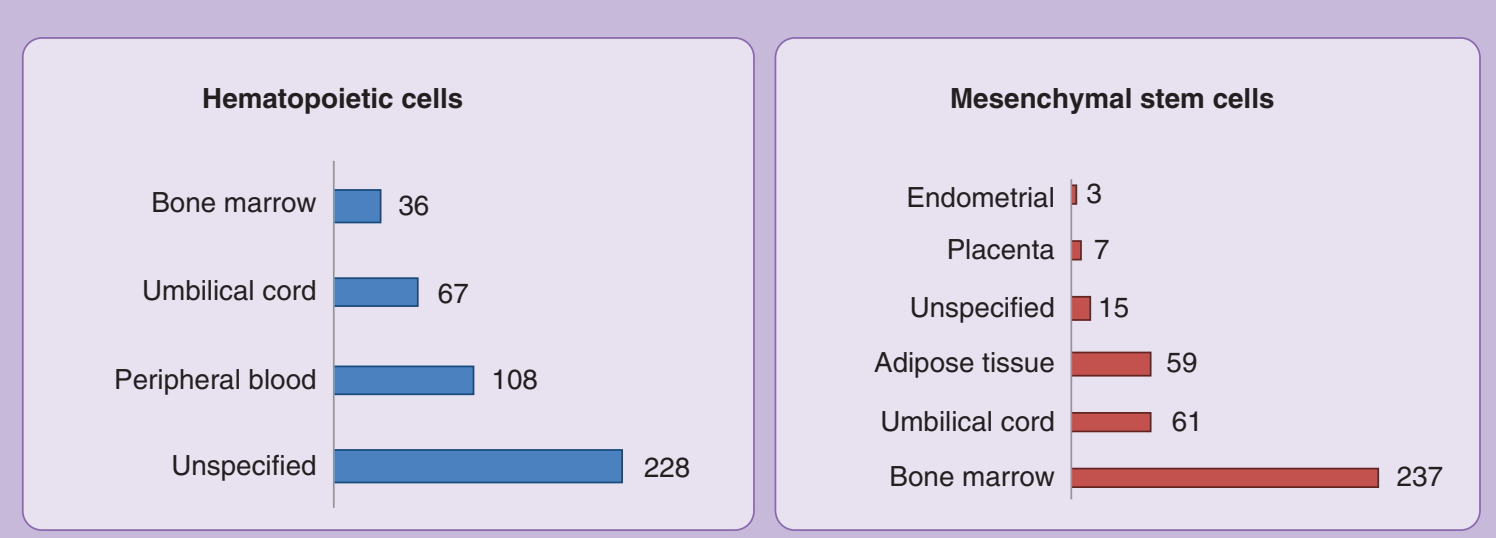

Figure 2. Current active cell therapy clinical trials showing the breakdown of the hematopoietic and mesenchymal stem cell groups the by cell isolation source.

and above. Neurological indications also represent a significant target for novel cell-based therapies for indications such as multiple sclerosis, stroke and motor neuron disease (Figure 4). Figure 3 shows the broad therapeutic utility adopted for MSCs, with clinical indications covering all 18 clinical categories with the majority within cardiovascular, neurological and autoimmune indications predominantly in Phase I. Likewise, tissue specific cells cover the majority of clinical indication categories, owing to the diversity of cell populations within this category.

\section{Cell-based therapy clinical trial phase}

It is unsurprising that the majority of cell-based therapy clinical trials are in Phase I, with 232 MSC, 146 lymphocyte and 118 hematopoietic cell clinical trials (Figure 5). There is however, an increase in hematopoietic cell clinical trials moving to Phase II with 187 compared with 116 in Phase I. There are also four tissue specific cell-based clinical trials that have reached postmarket surveillance, or Phase IV (Figure 5). Most notable of these are the use of dermal fibroblasts for wound repair from Arita Medical $\left(\mathrm{ReCell}^{\mathrm{TM}}\right.$ ) and Organogenesis (Apligraf ${ }^{\mathrm{TM}}$ ) as well as cell-based therapies to treat Type 2 diabetes and for cornea replacement. Figure 4 shows the major clinical categories by specific disease targets, with the vast majority targeting hematological malignancies within oncology, with equal weighting in Phases I and II. Cardiovascular indications also have a similar number of clinical trials in Phases I and II, with ten clinical trials in Phase III and above. MSC clinical trials are also well represented in Phase II $(\mathrm{n}=88)$ and are even seeing progression to Phase III (Figure 5). Neurology

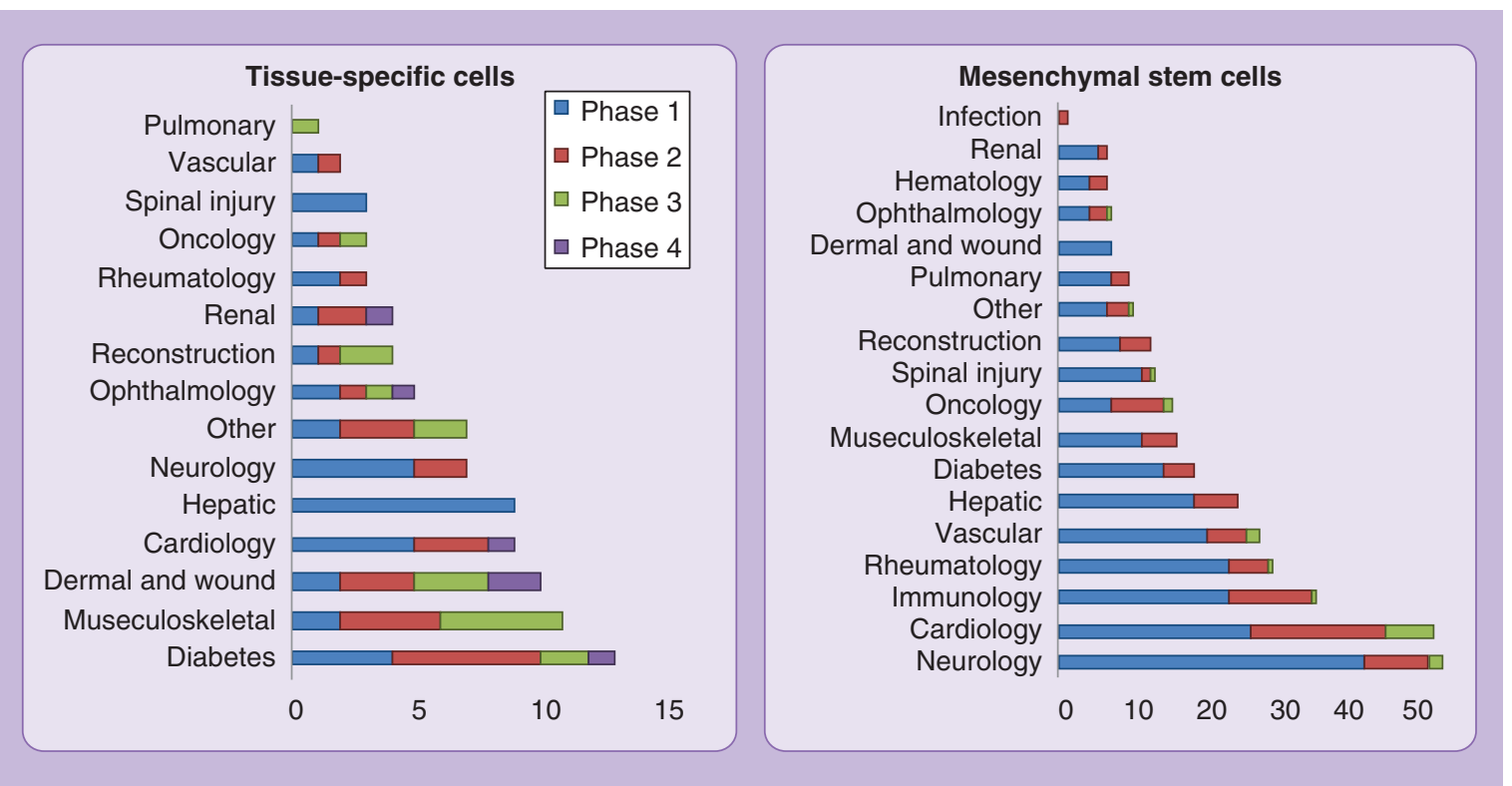

Figure 3. Current active cell therapy clinical trials involving tissue-specific cells (see Figure 1) and mesenchymal stem cells showing target clinical indication and current clinical trial phase. 


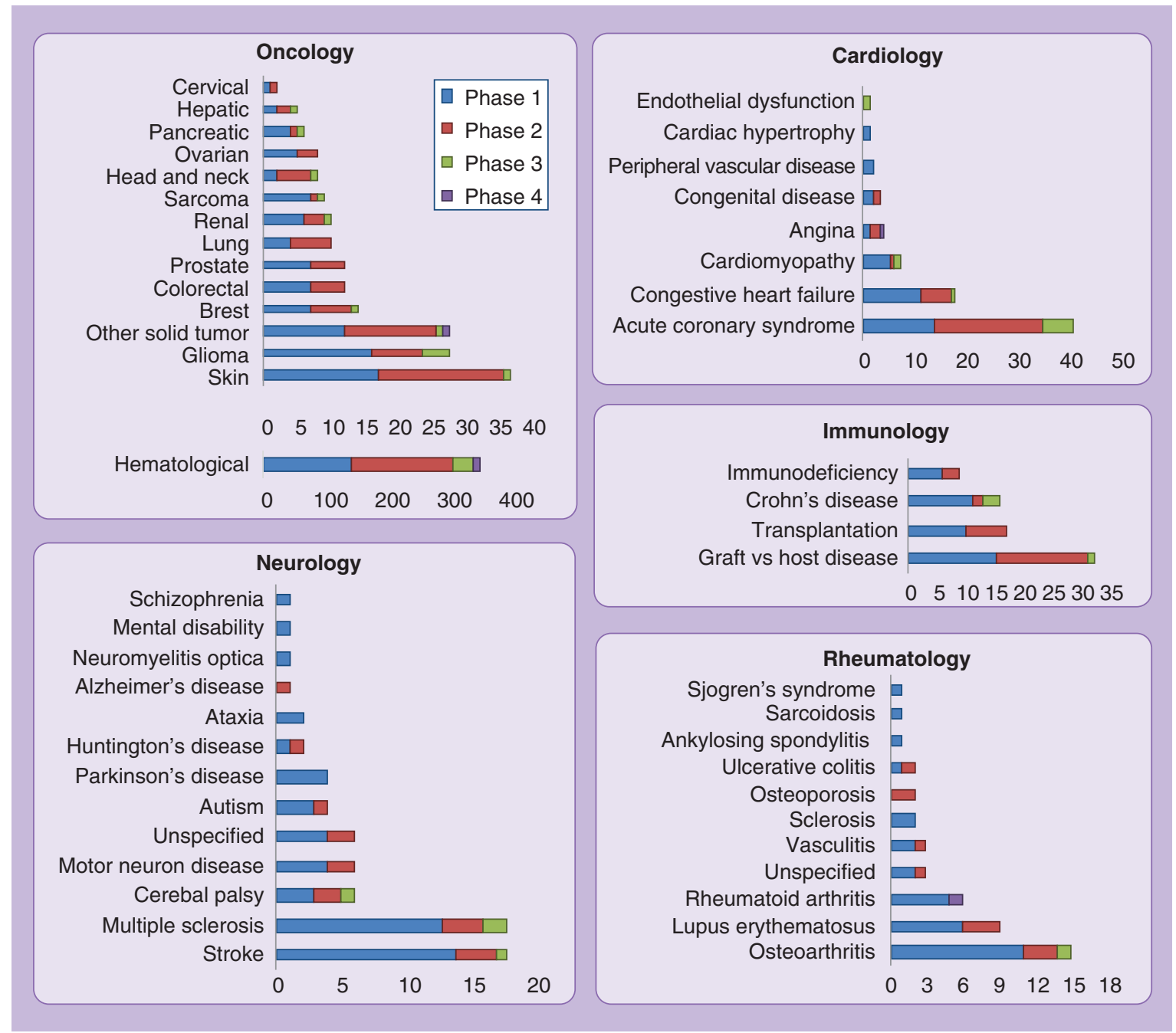

Figure 4. Breakdown of the most prevalent clinical target groups from cell therapy clinical trials by disease and trial phase.

and rheumatology based indications that involve MSCs are mostly in Phase I (Figure 6), however clinical development using bone marrow-derived MSCs to treat acute coronary syndrome, Crohn's disease and graft versus host disease are seeing progress into Phase II and above, with clinical trials taking place all over the world.

\section{Discussion}

Clinical translation of mesenchymal stem cell-based therapies

It is clear that outside of the traditional cell-based therapies using blood and immune cells to treat cancer, the majority of novel clinical trial activity is involving MSCs. The commercial pathway for MSC therapies was initiated after they were branded in 1991 by Arnold Caplan [3], leading to the generation of intellectual property by Osiris Therapeutics. The rebranding of MSCs has been used to generate intellectual property by defining a specific set of characterization criteria for the cell, for example, Athersys Inc. are developing a product termed MultiStem ${ }^{\mathrm{TM}}$, a Multipotent Adult Progenitor Cell therapy which has been patented under this name [32,33].

As the first clinical trials involving MSCs developed, the need for nomenclature and characterization standards led to the formation of the International Society for Cellular Therapy working group in 1992, who eventually published minimal criteria for MSCs in research [34,35]. The broad therapeutic utility currently adopted for MSC clinical indications was a product of work by Osiris Therapeutics [36] and led to a lot of publicity around the potential of stem cell-based therapies. The green shoots of industry that began to emerge in the 1990s soon dried up as the failure rate of clinical trials, the huge cash-burn and increased bankruptcy of cell-based therapy companies caused investors to lose confidence in the industry and as a 
result, the capital value of publicly traded companies plummeted from US $\$ 2.5$ billion in 2000 to US $\$ 300$ million by the end of 2002 [10]. This decline was predominantly driven by a lack of fundamental understanding of the therapeutic mechanism of action of MSCs in vivo which is still under discussion [37]. This understanding will be imperative, as relevant potency assays must be used to optimize manufacturing processes based on a single clinical indication, even if the same master cell line is to be used for multiple therapeutic targets.

Clinical work in the mid-2000s showed that the immunomodulatory properties of MSCs played a key role in their therapeutic potential [38,39], suppressing tissue rejection by inhibiting the response of the patient's lymphatic cells. This is reflected in Figure 6, as the use of MSCs for immunology and rheumatology based indications are common and are progressing through clinical development with five trials progressing to Phase III, one targeting osteoarthritis (Medipost), one targeting graft versus host disease (Mesoblast) and three targeting Crohn's disease (Tigenix and two by Mesoblast). This demonstrates the increased emphasis that industry has placed on the immunomodulatory mechanism of action that MSCs have demonstrated. The mounting evidence that the therapeutic effect of MSCs is not mediated by engraftment and terminal differentiation but by cell secreted trophic factors is gaining increasing momentum with studies showing that donor DNA is only retained in the lungs, lymph nodes and intestine following MSC infusion [40]. There is limited clinical evidence supporting the optimal method for therapeutic delivery of cell-based products [41] and it is likely that, as with manufacturing processes, delivery systems will be developed specifically for each therapeutic indication [42].

\section{Case study: product manufacture during Phase I clinical trial}

Since the discovery of embryonic stem cells in 1998 [43], pluripotent stem cells have been considered a promising source of allogeneic stem cells for regenerative therapies. In 2010 Geron Co. went into Phase I clinical trials with an allogeneic human embryonic stem cell (hESC)-derived oligodendrocyte progenitor product for the treatment of spinal cord injury. Despite no adverse safety issues with this hESC-derived therapy, Geron Co. halted the clinical trial citing financial and regulatory issues [44]. Currently, all of the clinical trials involving hESCs are targeting ophthalmology related indications, in Stargardt's macular dystrophy

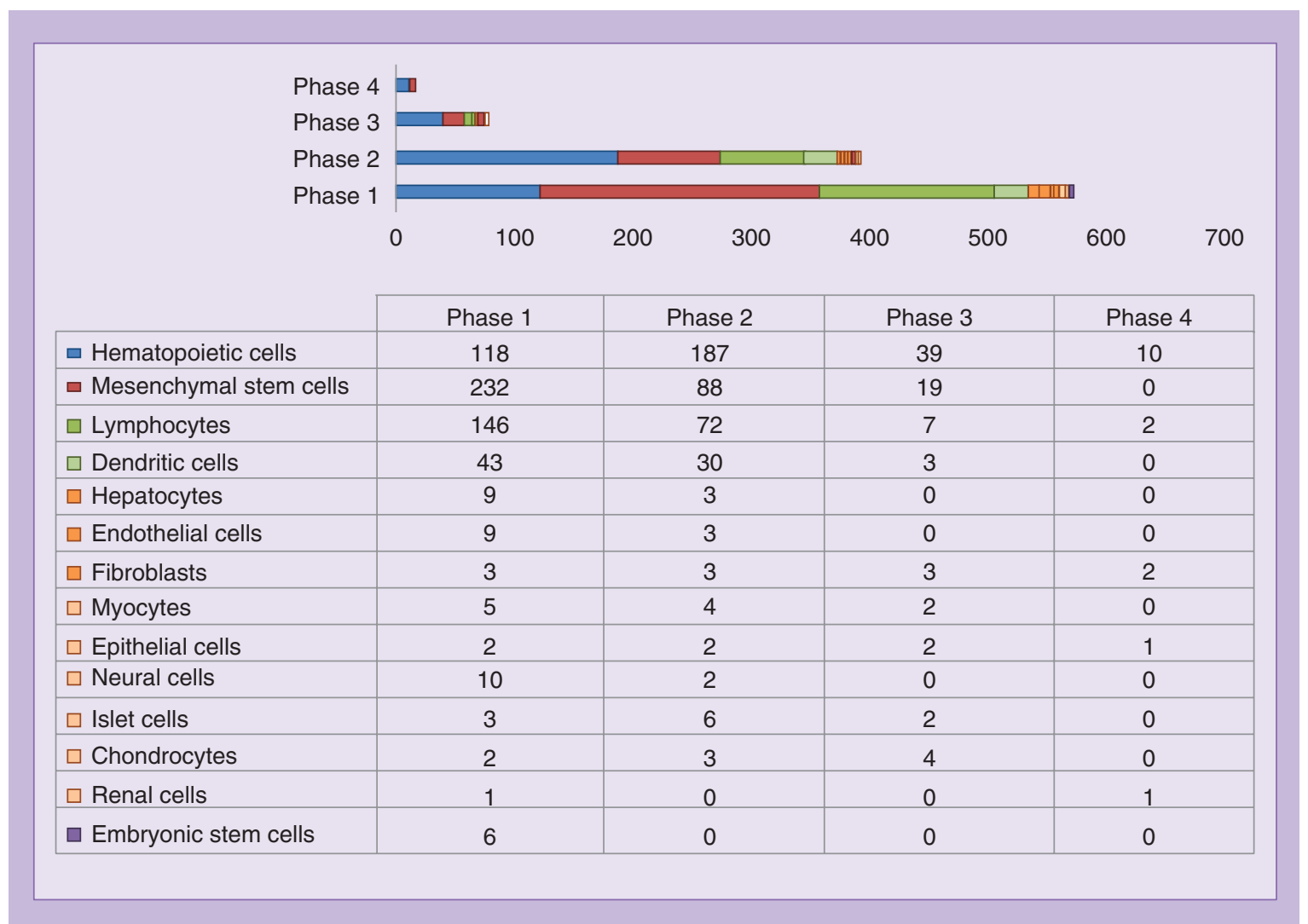

Figure 5. Breakdown of current active cell therapy clinical trials by cell group and trial phase. 


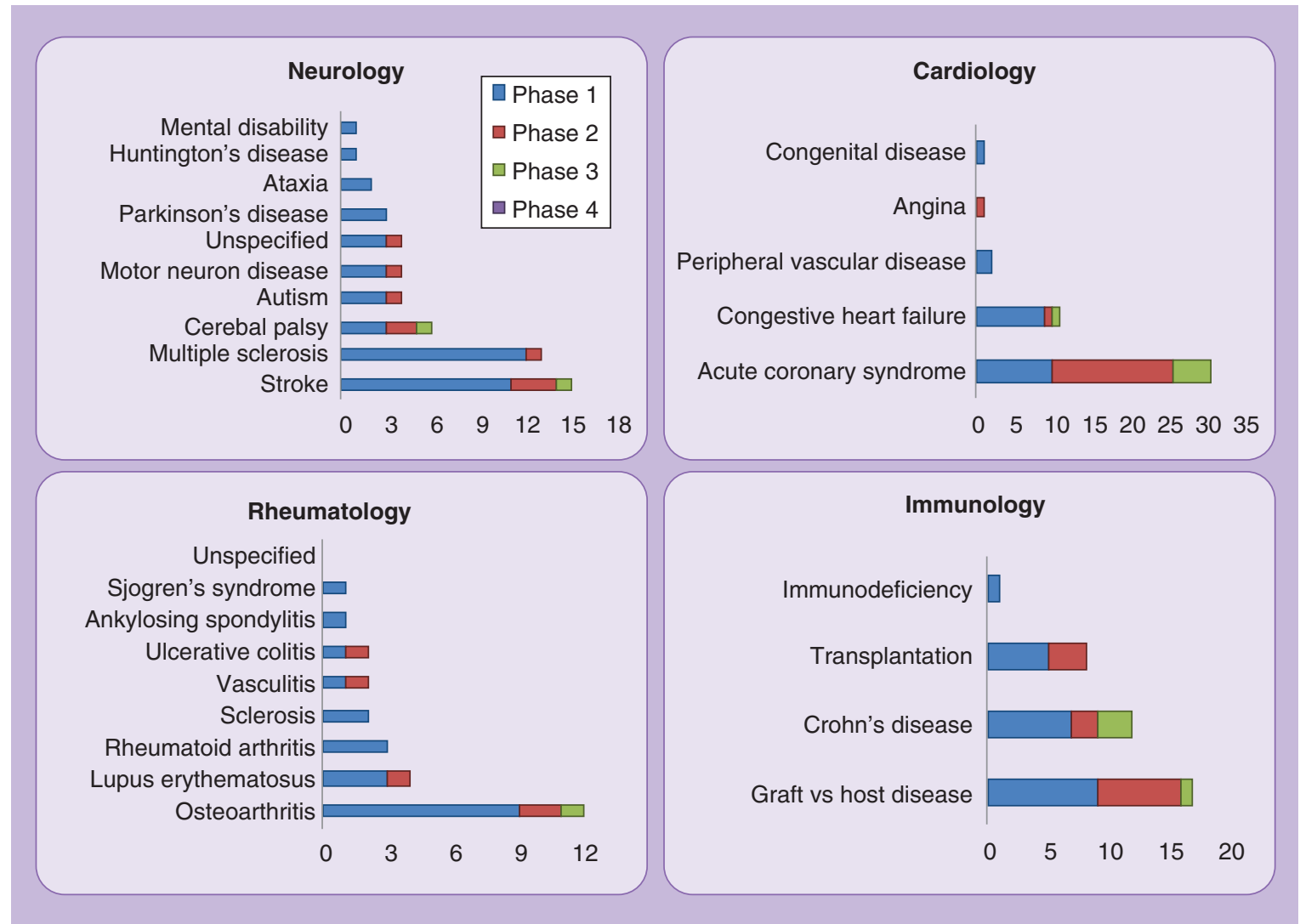

Figure 6. Current active cell therapy clinical trials involving mesenchymal stem cells showing target clinical indications by target disease and trial phase.

and dry age-related macular degeneration. Advanced Cell Technologies are sponsoring three of these clinical trials in the UK and USA, treating these disorders with hESC-derived retinal pigment epithelium (RPE) cells. One of the key challenges in the manufacture of a pluripotent product is in the differentiation of the hESC into the therapeutically active cell, which can dramatically impact product yield. The Advanced Cell Technologies RPE product is manufactured from the GMP-grade MA09 hESC line, cultured on mitomycin-inactivated murine embryonic fibroblasts for three passages. Following the formation of embryoid bodies, pigmented RPE patches are isolated and purified [45], before further expansion and cryopreservation for clinical use. Product characterization takes place in-process and postcryopreservation, in the form of pathogen testing, karyotype analysis and purity [46]. Much of this manufacturing process is labor-intensive and requires operator intervention, which may not be amenable to automated and scalable manufacture. Therefore, despite the positive safety data from these ESC clinical trials [44], it is clear that there are many manufacturing challenges that must be overcome before these therapies can be translated through clinical trial and into commercial production.

\section{Case study: manufacture for commercial production}

It is clear from the clinical trial results in Figure 1, that the most prevalent clinical category for cell based therapies is in oncology, with immune cells contributing to around half of these cell-based therapies. Sipuleucel-T is an autologous active cell-based immunotherapy product designed to stimulate an immune response against prostate cancer from Dendreon Corporation (WA, USA) [47]. In 2010, Sipuleucel-T (Provenge ${ }^{\circledR}$ ) became the first FDA-approved autologous cell-based therapy, providing a scale-out service based approach to product manufacture and delivery. Patient cells are collected via leukapheresis [48] and cold shipped to a manufacturing site, where the cells are manipulated under GMP conditions to isolate and activate the target immune cells. The activated cell-based immune therapy is then cold shipped back to the patient to be reinfused, which is repeated three times to deliver the full therapeutic dose. Dendreon Corporation operates patient logistics from a central location, with distributed manufacturing taking place at multiple sites across the USA. This product handling and manipulation is largely manual and has led to high product operating costs, increasing the product cost of goods and therefore creating a high 
reimbursement price, which is US $\$ 93,000$ per patient. Efforts have been made to reduce the cost of goods by implementing automated process steps, with the intention of reducing these high operating costs. This case study highlights the importance of considering functionally closed and automated scale out processes early in clinical development as this will reduce the overall cost of goods during commercial production [49].

A proposed clinical development pathway would be to produce Phase I material in a manual, semiclosed process which could then be transferred to a scalable, closed and automated manufacturing process following the success of the initial clinical trials. This model would allow for reduced capital investment to evaluate the product at Phase I but then would transfer the process in a timely manner, ensuring a scalable and cost effective product supply for late stage clinical development and commercial supply. Considering the high cost and increased risk of validating sterilization cycles, it is likely that these closed-processes will utilize disposable technology, mimicking current therapeutic protein process development [50].

\section{Progress from clinical development to product manufacture}

Industry progression towards the successful manufacture of cell-based therapies is evident by international cooperation on the formation of global reference 'ruler' standards and protocols to facilitate manufacturing comparability of MSCs [51]. This will facilitate the development of consistent manufacturing processes across multiple sites and allow for a method to define each cell line. Defining desirable product characteristics is critical and will form the basis of release tests as well as setting the tolerances on the process, allowing for systematic product development and optimization.

A further sign that the commercial market for MSC application is increasing in competitiveness is the drive by companies such as Athersys and Osiris to clearly differentiate their product and its production process from 'generic' hMSCs. This phenomenon parallels the clinical development of MACI ${ }^{\mathrm{TM}}$ (by Genzyme) and $\mathrm{CCI}^{\mathrm{TM}}$ (by TiGenix) where companies actively sought to distance their products from legacy clinical data on the use of Autologous Chondrocyte Implantation, which was inconclusive in demonstrating costeffectiveness [14]. This approach to cell-based product development is largely driven by a fundamental lack of understanding of the product mechanism of action, as companies must differentiate their product to avoid a race to the bottom, whereby a lower cost therapy has an increased chance of reimbursement. Without the knowledge of the how these cell-based therapies elicit therapeutic benefit, manufacturing processes cannot be optimized to maximize this function and will inevitably be surpassed by lower cost therapies. Given the importance of regulation on the production of cellbased therapies, it is perhaps unsurprising that in the race to successfully commercialize cell products, companies have begun to raise the regulatory bar as a tactic to disrupt competitor companies. This action has the potential to hinder smaller companies who do not have the financial resource to comply with this increasing regulatory burden.

A further hallmark of the commercial progress of MSC therapies is the move towards developing automated processes as well as the implementation of functionally closed manufacturing systems and consideration of the associated logistics, supply chain and cost of goods [52]. Significant UK government investment in the form of the Cell Therapy Catapult has been tasked with 'derisking' cell-based therapy development for industry by providing a 'center of excellence' to bridge the current translation gap in the industry [53]. Outside of the UK, additional institutes have been established to provide resources in Canada (Centre for Commercialization of Regenerative Medicine) and the USA (California Institute for Regenerative Medicine and the National Institutes of Health) to facilitate this translational process. Despite this progress, there remains a requirement for a better understanding of potential manufacturing platforms and how they can be best utilized for cell-based therapy production.

\section{Expansion technologies to achieve clinical scale manufacture}

With cell-based therapies moving towards commercialization and multiple clinical trials in late stage development, it is clear that selecting suitable manufacturing technology is becoming increasingly important. It is imperative that potential pitfalls in developing scalable manufacturing methods are identified at an early stage and strategies are implemented that can streamline this development pathway (Table 1). A key consideration for streamlining this pathway is the tradeoff between clean room space and ongoing commercial supply as patient numbers increase from clinical development to commercial production. For an autologous therapy if you were treating, for example, 100 patients in a typical 2-week process for a Phase III clinical trial, you would likely require four clean room facilities in order to separate each patient lot. This is assuming that the process is not entirely closed and therefore each lot must be segregated to avoid cross contamination. The issues then arise if the product is successful and commercial production is carried out using the same process for say 1000 or even 10,000 patients per year, where the clean room and personnel requirements increase 
Table 1. Strategies for streamlining the path to scaled clinical manufacturing.

$\begin{array}{ll}\text { Process requirement } & \text { Description } \\ \text { Implement end to end } & \text { Utilize upstream and downstream processes } \\ \text { closed processing } & \begin{array}{l}\text { that can be interconnected in a functionally } \\ \text { closed manner }\end{array}\end{array}$

Benefits from implementation

While manufacturing systems are becoming

functionally closed, the reliance on open

or non-closed inter process steps and

manipulations necessitates the use of a clean

room facility - massively increasing fixed costs of manufacture

Use processing steps and Maximize product output for a given processes with the highest master cell bank population or donor cell practicable expansion ratio $^{\dagger}$ population

Increase process capability Increase stability and consistency of individual process outputs

Increase inter-process pooling tolerances

Keep COGS low in short term while maintaining

cost headroom

Implement intermediate cryopreservation stages
All manufacturing platforms have a limit in the amount of surface area that can be manipulated (seeded or harvested) per unit time. This limit, in combination with cell pooling time tolerances between processing stages limits the effective batch size that may be cultured

Develop a process that has a (realistic) reimbursable price point at all stages of scale, as market adoption rates are typically slow
Any reduction in the number of unit processes that must be validated to pass through process qualification significantly reduces the cost of pre- and post-market validation

Reduce process output variation will provide a more consistent utilization of a manufacturers fixed cost base. This in turn improves operational costs and reduces overall COGS

Increase in overall batch size that may be achieved. For scale out systems such as closed single use bioreactors or the manual/automated manipulation of planar vessels an increase in pooling time tolerance could yield cost reductions in the form of reduced manufacturing labor, increased capacity utilization

Cell therapy manufacturing companies with approved products have struggled to achieve routine reimbursement at a level that would enable investment in facilities and process improvements that would reduce their costs. This effectively traps companies in a difficult financial position. Companies that maintain low COGS during clinical development can reinvest in process improvement and scale as they enter the market

Autologous - implement a cryopreservation In allogeneic manufacturing intermediate step between manufacturing and product delivery

Allogeneic - implement multiple in-process banking stages between cell sourcing, expansion and product delivery cryopreservation stages allow a more efficient use of master bank cell populations at low production capacities. Its also allows different stages of the process to be scaled up independently, allowing a staged validation program. In both autologous and allogeneic manufacturing strategies this reduces the need to release products at risk before end stage quality and safety testing is complete

Expansion ratio defined as the output of cells divided by the input population.

10-fold or 100-fold respectively, making the product cost-prohibitive at this scale. This will drive the development of expansion platforms that are fully closed, so that multiple patient lots can be manufactured in the same facility, greatly reducing fixed and operating costs as the product moves toward commercial production. Table 2 shows the number doses per lot achievable for multiple expansion technologies currently available based on an allogeneic MSC treatment for myocardial infarction [54] requiring 35-350 million cells per dose.
This demonstrates the challenge of manufacturing an MSC based product for 10,000 patients per year, given the number of doses per lot achievable using current expansion technology.

A manufacturing process that reduces biological divergence will inevitably yield a more consistent and higher quality product. This biological divergence is typical of cell expansion processes, whereby small changes to the cell environment at the start of culture will lead to large changes by the time the product is 
harvested. This has been demonstrated in the culture of embryonic stem cells whereby changes to dissolved oxygen levels in the culture medium can lead to changes in cell growth characteristics [55] and differentiation potential [56]. This potential divergence can be limited by reducing the heterogeneity of the culture conditions via mixing, so that the cell microenvironment remains consistent throughout the culture. Technology that does not induce mixing such as T-flasks will potentially suffer from heterogeneity in physical, chemical and hence physiological conditions, although it can also exist in other forms. Packed/fluidized-bed bioreactors, due to their high density will invariably suffer from axial concentration gradients as medium flows though the bed, particularly as the scale increases. Hollow fiber reactors have the potential to introduce heterogeneity via longitudinal concentration gradients as medium or dissociation reagent flowing down the bioreactor changes with distance through the fiber (under plug flow). Although these factors could impact the consistency of the product, there is a lack of evidence to back this up and far more work will be required to fully understand and develop the various manufacturing processes for cell-based therapies.

A lack of online process control is a key barrier for the consistent manufacture of cell-based therapies. Expansion technologies such as rotating flasks and multilayer flasks lack the capability for online cell visualization which could form the basis for a noninvasive control strategy based on cell coverage of a surface [57]. These technologies as well as T-flask automation currently lack the ability for online medium sampling which prohibits the control of key nutrient and metabolite concentrations, a staple of process control in the bioprocessing industry. Without an effective process control metric, expansion technology will suffer when attempting to maintain product consistency and will incur a higher cost for product validation. Process control strategies are poorly understood for novel cell expansion technologies, however are routine in stirred tank bioreactors for current bioprocesses [58,59]. In addition to this, the physical characterization of the stirred reactor system is well understood and can also be directly translated from traditional bioprocesses [60-62]. This development is analogous to process analytical technology (PAT) [63] in the current biopharmaceutical industry [64] and could be used as a model for the cell-based therapy process development.

The efficient harvest of cell-based therapies represents one of the few deviations from traditional bioprocessing and must be designed based on cell sensitivity and the pooling time limitations of the product. Scaleout processes such as rotating flasks [65,66], T-flasks [22] and multilayer flasks [67] will require high cell pooling times which will limit the effective scale to which these therapies can be manufactured as product quality will likely reduce during the pooling process (Table 2). For cell-based therapies that are surface-adherent, the dissociation of the cell from the surface is required during the expansion process. This unique constraint of cell-based therapy manufacture is often overlooked but has been considered for packed/fluidized bed [68], hollow fiber [69] and stirred tank bioreactors [70]. Rocking-motion $[71,72]$ and pneumatically driven bioreactors [62,73] have been previously employed for suspension cell culture. However, transferring these systems to surface-adherent cell types will likely require an additional process step to transfer the culture to a

\begin{tabular}{|c|c|c|c|c|c|c|c|c|}
\hline \multicolumn{2}{|c|}{ Expansion technology } & \multicolumn{3}{|c|}{ Estimated scale per lot } & \multicolumn{2}{|c|}{ Estimated doses per lot } & \multicolumn{2}{|c|}{ Adherent cell harvest } \\
\hline & & $\begin{array}{l}\text { Surface } \\
\text { area, } \mathrm{cm}^{2}\end{array}$ & $\begin{array}{l}\text { Harvest } \\
\text { volume, I }\end{array}$ & $\begin{array}{l}\text { Number of } \\
\text { cells (billion) }\end{array}$ & $\begin{array}{l}35 \text { million } \\
\text { cells per } \\
\text { dose }\end{array}$ & $\begin{array}{l}350 \text { million } \\
\text { cells per } \\
\text { dose }\end{array}$ & $\begin{array}{l}\text { Detachment } \\
\text { efficiency }\end{array}$ & $\begin{array}{l}\text { Pooling } \\
\text { time }\end{array}$ \\
\hline \multirow[t]{5}{*}{ Adherent } & Rotating flasks & 850,000 & 100 & 21.30 & 609 & 61 & Low & High \\
\hline & Packed/fluidized & 440,000 & 5 & 11.00 & 314 & 31 & Medium & Medium \\
\hline & Hollow fiber & 210,000 & 5 & 0.50 & 14 & 1 & Medium & Medium \\
\hline & $\begin{array}{l}\text { T-flask } \\
\text { (automated) }\end{array}$ & 225,000 & 50 & 0.56 & 16 & 2 & High & High \\
\hline & Multilayer flask & 400,000 & 30 & 10.00 & 286 & 29 & High & High \\
\hline \multirow{3}{*}{$\begin{array}{l}\text { Adherent } \\
\text { and } \\
\text { suspension }\end{array}$} & Stirred tank & $>4,000,000$ & $>1000$ & $>100.00$ & $>2857$ & $>286$ & High & Low \\
\hline & Rocking-motion & $2,000,000$ & 500 & 50.00 & 1429 & 143 & Low & Low \\
\hline & $\begin{array}{l}\text { Pneumatically } \\
\text { driven }\end{array}$ & $2,000,000$ & 500 & 50.00 & 1429 & 143 & Low & Low \\
\hline
\end{tabular}


harvest vessel, allowing for increased agitation to promote efficient detachment and harvest of cells from microcarriers, which may not be sufficient in these systems [74]. A further challenge will emerge if the cells are required to be dissociated during the process (i.e., if bead-to-bead transfer does not occur at a high enough rate to support one step expansion). This will add additional steps to the process and will likely influence the design and optimization of other aspects of the process, such as agitation strategy and culture medium.

Although much work is yet to be done on calculating the optimum volume for expanding cell-based products in stirred tank reactors, current estimates put the maximum value at around 10001 [75]. It should be noted however, that industrial scale mammalian cell culture, once considered to be limited to a similar scale is now routinely operated at greater than $10,0001[62,76]$. Similar gains in effective cells per batch can also be made by increasing the microcarrier concentration, which is currently far from optimal for suspension based systems [77].

One feature that is a fundamental aspect of all culture processes is the need to supply oxygen to the cells. Due to its limited solubility, this supply is required to be provided continuously. As the cell density increases, it becomes necessary to provide that oxygen by sparging; typically with air, which also strips out the carbon dioxide produced [78]. For free suspension animal cells, sparging has required the inclusion in the media of protective agents, almost always the surfactant, Pluronic $^{\mathrm{TM}} \mathrm{F} 68$, as bursting bubbles are detrimental to cell viability [62]. Because the cell densities reached to date and the specific oxygen uptake rate of MSCs [77] and embryonic stem cells [79], for example, are both low, such issues have not yet been addressed but will need to be as the density increases, especially since the presence of these protective agents in final product formulations may be an issue. For pneumatically driven bioreactors $[62,73]$, bubbling gas is inherent to the way they function and therefore potential cell damage must be considered during the appraisal of expansion technology.

It is clear that other than stirred bioreactors, there is a distinct lack of comparable and peer reviewed data for the majority of manufacturing platforms discussed in this study. This could potentially be to the detriment of the field, as without reliable information to inform technology appraisal, process development is likely to default to stirred tank bioreactors due to the strong legacy data that exists for large scale mammalian cell culture. On the other hand, there is nothing to be gained by innovating unnecessarily. Many of the potential manufacturing platforms mentioned here were considered in the 1980s for culturing animal cells, when it was considered that because they lacked a cell wall, it would be impossible to do so in the presence of rotating stirrers. Yet today, whether in single use systems, at bench scale or the largest commercial scale, stirred bioreactors are commonplace in the biotechnology industry [80]. Indeed, they are now being preferred industrially even for clone selection in robotically controlled microbioreactors $\left(\mathrm{ambr}^{\mathrm{TM}}\right)$ at the $15 \mathrm{ml}$ scale [81].

\section{Conclusion}

Providing an overview of the current cell-based therapy landscape has shown the breadth and diversity of the current cell-based therapies in clinical development. With an increasing number of cell types and clinical indications being assessed, it is clear that consideration must be given to how these products will be manufactured and subsequently delivered to patients on a clinically relevant scale. Although, several manufacturing systems are already available for the expansion and manipulation of therapeutically relevant cells, an optimal and universal manufacturing platform does not yet exist and may not be attainable due to the variety of cell types and clinical applications. With the exception of MSCs, most therapeutically relevant cell types have only been demonstrated on a subset of the broad range of available platforms. Developers considering the range of available manufacturing technologies need to balance the competing pressures discussed. Nevertheless, the fact that both MSC culture and harvest have now been effectively demonstrated in stirred bioreactors based on sound physical principles is encouraging, especially given the inherent flexibility and controllability of this technology; and its success with free suspension and adherent animal cells from the $15 \mathrm{ml}$ to the 25,000 1 scale.

As an industry, cell-based therapies are still in the early stages of clinical development. It is clear that we must better understand the quality of our cell-based products in order to form a stable base for process evaluation and development. Investment in cell-based therapy manufacturing in the UK has created an urgent need to better understand these cell-based therapy products to facilitate successful manufacture based on strong clinical data demonstrating product efficacy. It is likely that there will be bespoke manufacturing processes for each of these cell-based products as well as 'generic' cell-based therapy products driven by this fundamental lack of product understanding, with a move toward functionally closed and single-use technology.

\section{Future perspective}

Moving forward, we must better characterize cellbased therapy clinical trials with accessible information for a host of variables, including cell dose, patient numbers and cell providence. This will allow for effi- 
cient and accurate data collection on cell-based therapy clinical trials, facilitating decision making across the cell-based therapy sector. As understanding of the cell-based products increases, we will likely experience step change improvements in manufacturing capability. However, despite the current progress, we must recognize that cell-based therapy is still a relatively green industry with great potential yet to be realized.

\section{Open Access}

This work is licensed under the Creative Commons Attribution-NonCommercial 3.0 Unported License. To view a copy of this license, visit http://creativecommons.org/licenses/bync-nd/3.0/

\section{Author contribution}

CJ Hewitt, B Kara and AW Nienow designed the research questions; TRJ Heathman developed the clinical trial selection framework and completed the data analysis; TRJ Heathman,
B Kara and MJ McCall compiled the manufacturing data; and TRJ Heathman drafted the manuscript for publication.

\section{Acknowledgements}

The authors would like to thank Dr Deyna Cardosa, Specialist Registrar at Guy's and St Thomas' NHS Trust for assistance with disease categorization within the clinical trial framework.

\section{Financial \& competing interests disclosure}

This study has been funded by the Engineering and Physical Sciences Research Council and FUJIFILM Diosynth Biotechnologies. B Kara is a director of science and technology at FUJIFILM Diosynth Biotechnologies. The authors have no other relevant affiliations or financial involvement with any organization or entity with a financial interest in or financial conflict with the subject matter or materials discussed in the manuscript apart from those disclosed.

No writing assistance was utilized in the production of this manuscript.

\section{Executive summary}

\section{Aims}

- Inform industry and academia of current clinical activity involving the cell type with which they work.

- Identify gaps in the manufacturing requirements for cell-based therapies.

Materials \& methods

- Searched for the term 'cell' on ClinicalTrials.gov to include all clinical trials involving the use of cells up to 1 January 2014.

- Results were further sorted on the database to show only open trials that conformed to the definition of a cell-based therapy.

\section{Clinical translation of mesenchymal stem cell-based therapies}

- Lack of fundamental understanding of the therapeutic mechanism of action of MSCs in vivo must be overcome to facilitate process development and optimization.

- There is limited clinical evidence supporting the optimal method for delivery of cell-based products and it is likely that they will be developed specifically for each therapeutic indication.

Progress from clinical development to product manufacture

- Progress reflected by development of automated processes, reference standards and implementation of functionally closed manufacturing systems.

- Companies must differentiate their product to avoid a race to the bottom, whereby a lower cost therapy has an increased chance of reimbursement.

Expansion technologies to achieve clinical scale manufacture

- Imperative that potential pitfalls in developing scalable manufacturing methods are identified at an early stage and strategies are implemented that can streamline this development pathway.

- Consideration must be given to cell harvest and pooling time limits as they represent key deviations from traditional bioprocesses.

- Other than stirred reactors with cells attached to microcarriers, there is a lack of comparable data for the majority of the cell-based manufacturing technologies.

\section{Conclusion}

- Multiple manufacturing platforms will likely be required to cover the diversity of cell types, clinical indications and business models.

- A greater understanding of cell quality metrics are required for bioprocess development.

Future perspective

- Need to better characterize cell-based therapy clinical trials and data should be immediately accessible.

- As understanding of the cell-based products increases, we will likely experience step change improvements in manufacturing capability.

- Despite the current progress, we must recognize that cell-based therapy is still a relatively green industry with great potential yet to be realized. 


\section{References}

Papers of special note have been highlighted as:

- of interest; $\bullet \bullet$ of considerable interest

1 Mason C, McCall MJ, Culme-Seymour EJ et al. The global cell therapy industry continues to rise during the second and third quarters of 2012. Cell Stem Cell 11(6), 735-739 (2012).

2 Tavassoli M, Crosby WH. Transplantation of marrow to extramedullary sites. Science 161(3836), 54-56 (1968).

3 Caplan AI. Mesenchymal stem cells. J. Orthop. Res. 9(5), 641-650 (1991).

4 Pittenger MF, Mackay AM, Beck SC et al. Multilineage potential of adult human mesenchymal stem cells. Science 284(5411), 143-147 (1999).

5 Culme-Seymour EJ, Davie NL, Brindley DA, EdwardsParton S, Mason C. A decade of cell therapy clinical trials (2000-2010). Regen. Med. 7(4), 455-462 (2012).

- First study surveying the clinical trial landscape for cellbased therapies, which has led to subsequent clinical trial analysis.

6 Trounson A, Thakar RG, Lomax G, Gibbons D. Clinical trials for stem cell therapies. BMC Med. 9, 52 (2011).

7 Li MD, Atkins H, Bubela T. The global landscape of stem cell clinical trials. Regen. Med. 9(1), 27-39 (2014).

8 Pera MF. Stem cells. The dark side of induced pluripotency. Nature 471(7336), 46-47 (2011).

9 Mason C, Manzotti E. Regenerative medicine cell therapies: numbers of units manufactured and patients treated between 1988 and 2010. Regen. Med. 5(3), 307-313 (2010).

10 Lysaght MJ, Hazlehurst AL. Tissue engineering: the end of the beginning. Tissue Eng. 10(1-2), 309-320 (2004).

11 Mason C, Manzotti E. Defeating stem cell tourism. Foreword. Regen. Med. 5(5), 681-686 (2010).

12 Daley GQ. The promise and perils of stem cell therapeutics. Cell Stem Cell 10(6), 740-749 (2012).

13 Hyun I, Lindvall O, Ahrlund-Richter L et al. New ISSCR guidelines underscore major principles for responsible translational stem cell research. Cell Stem Cell 3(6), 607-609 (2008).

14 Hourd P, Chandra A, Medcalf N, Williams DJ. Regulatory challenges for the manufacture and scale-out of autologous cell therapies. In: StemBook (Internet). Harvard Stem Cell Institute, MA, USA (2008).

15 Kirouac DC, Zandstra PW. The systematic production of cells for cell therapies. Cell Stem Cell 3(4), 369-381 (2008).

16 Thomas RJ, Hourd PC, Williams DJ. Application of process quality engineering techniques to improve the understanding of the in vitro processing of stem cells for therapeutic use. J. Biotechnol. 136(3-4), 148-155 (2008).

17 Mason C, Manzotti E. Regen: the industry responsible for cell-based therapies. Regen. Med. 4(6), 783-785 (2009).

18 Bravery CA, Carmen J, Fong T et al. Potency assay development for cellular therapy products: an ISCT review of the requirements and experiences in the industry. Cytotherapy 15(1), 9-19 (2013).
- Review of the requirements for defining and measuring the quality of cell-based therapies, which is a key step in their successful manufacture.

19 Moll G, Hult A, Von Bahr L et al. Do ABO blood group antigens hamper the therapeutic efficacy of mesenchymal stromal cells? PLoS ONE 9(1), e85040 (2014).

20 Rayment EA, Williams DJ. Concise review: mind the gap: challenges in characterizing and quantifying cell- and tissuebased therapies for clinical translation. Stem Cells 28(5), 996-1004 (2010).

21 Williams DJ, Thomas RJ, Hourd PC et al. Precision manufacturing for clinical-quality regenerative medicines.

Philos. Trans. A Math. Phys. Eng. Sci. 370(1973), 3924-3949 (2012).

- Outlines the importance of precision manufacturing in regenerative medicine and the requirements for the manufacturing technology.

22 Thomas RJ, Chandra A, Liu Y, Hourd PC, Conway PP, Williams DJ. Manufacture of a human mesenchymal stem cell population using an automated cell culture platform. Cytotechnology 55(1), 31-39 (2007).

23 Thomas RJ, Anderson D, Chandra A et al. Automated, scalable culture of human embryonic stem cells in feeder-free conditions. Biotechnol. Bioeng. 102(6), 1636-1644 (2009).

24 Thomas RJ, Hope AD, Hourd P et al. Automated, serum-free production of CTX0E03: a therapeutic clinical grade human neural stem cell line. Biotechnol. Lett. 31(8), 1167-1172 (2009).

25 Liu Y, Hourd P, Chandra A, Williams DJ. Human cell culture process capability: a comparison of manual and automated production. J. Tissue Eng. Regen. Med. 4(1), 45-54 (2010).

26 Mason C, Hoare M. Regenerative medicine bioprocessing: the need to learn from the experience of other fields. Regen. Med. 1(5), 615-623 (2006).

27 Mason C, Dunnill P. Assessing the value of autologous and allogeneic cells for regenerative medicine. Regen. Med. 4(6), 835-853 (2009).

28 European Medicines Agency. European Public Assessment Report: Provenge (2013)

www.ema.europa.eu/ema/index.jsp?curl=pages/medicines $/$ human/medicines/002513/human_med_001680. jsp\&mid=WC0b01ac058001d124

29 Clinical Trials.gov. http://clinicaltrials.gov

30 Cell therapy and regenerative medicine glossary. Regen. Med. 7(Suppl. 3), S14-S116 (2012).

31 Zarin DA, Tse T, Williams RJ, Califf RM, Ide NC. The clinicaltrials.gov results database - update and key issues. N. Engl. J. Med. 364(9), 852-860 (2011).

32 Breyer A, Estharabadi N, Oki M et al. Multipotent adult progenitor cell isolation and culture procedures. Exp. Hematol. 34(11), 1596-1601 (2006).

33 Jiang Y, Vaessen B, Lenvik T, Blackstad M, Reyes M, Verfaillie CM. Multipotent progenitor cells can be isolated from postnatal murine bone marrow, muscle, and brain. Exp. Hematol. 30 (8), 896-904 (2002). 
34 Horwitz EM, Le Blanc K, Dominici M et al. Clarification of the nomenclature for MSC: The International Society for Cellular Therapy position statement. Cytotherapy 7(5), 393-395 (2005).

35 Dominici M, Le Blanc K, Mueller I et al. Minimal criteria for defining multipotent mesenchymal stromal cells. The International Society for Cellular Therapy position statement. Cytotherapy 8(4), 315-317 (2006).

Pittenger MF. Multilineage potential of adult human mesenchymal stem cells. Science 284(5411), 143-147 (1999).

37 Bianco P, Cao X, Frenette PS et al. The meaning, the sense and the significance: translating the science of mesenchymal stem cells into medicine. Nat. Med. 19(1), 35-42 (2013).

- Perspective on the importance of understanding the identity and function of mesenchymal stem cells (MSCs) and the impact on successful clinical translation.

38 Le Blanc K, Rasmusson I, Sundberg B et al. Treatment of severe acute graft-versus-host disease with third party haploidentical mesenchymal stem cells. Lancet 363(9419), 1439-1441 (2004).

- $\quad$ Clinical study demonstration the in vivo immunomodulatory properties of MSCs leading to shift in clinical use for MSCs.

39 Le Blanc K, Frassoni F, Ball L et al. Mesenchymal stem cells for treatment of steroid-resistant, severe, acute graft-versushost disease: a Phase II study. Lancet 371(9624), 1579-1586 (2008).

40 Von Bahr L, Batsis I, Moll G et al. Analysis of tissues following mesenchymal stromal cell therapy in humans indicates limited long-term engraftment and no ectopic tissue formation. Stem Cells 30(7), 1575-1578 (2012).

41 Kean TJ, Lin P, Caplan AI, Dennis JE. MSCs: delivery routes and engraftment, cell-targeting strategies, and immune modulation. Stem Cells Int. 2013, 732742 (2013).

42 Coopman K, Medcalf N. From production to patient: challenges and approaches for delivering cell therapies. In: StemBook. Harvard Stem Cell Institute, MA, USA (2014).

43 Thomson JA, Itskovitz-Eldor J, Shapiro SS et al. Embryonic stem cell lines derived from human blastocysts. Science 282(5391), 1145-1147 (1998).

44 Atala A. Human embryonic stem cells: early hints on safety and efficacy. Lancet 379(9817), 689-690 (2012).

45 Lu B, Malcuit C, Wang $S$ et al. Long-term safety and function of RPE from human embryonic stem cells in preclinical models of macular degeneration. Stem Cells 27(9), 2126-2135 (2009).

46 Schwartz SD, Hubschman J-P, Heilwell G et al. Embryonic stem cell trials for macular degeneration: a preliminary report. Lancet 379(9817), 713-720 (2012).

47 Small EJ, Schellhammer PF, Higano CS et al. Placebocontrolled phase III trial of immunologic therapy with sipuleucel-T (APC8015) in patients with metastatic, asymptomatic hormone refractory prostate cancer. J. Clin. Oncol. 24(19), 3089-3094 (2006).

48 Kantoff PW, Higano CS, Shore ND et al. Sipuleucel-T immunotherapy for castration-resistant prostate cancer. N. Engl. J. Med. 363(5), 411-422 (2010).
49 Hampson B. Closed processing for cell therapies: engineering risk reduction and patient safety during manufacturing. Genetic Enginerring and Biotechnology News, 1 May (2014).

50 Kuczewski M, Schirmer E, Lain B, Zarbis-Papastoitsis G. A single-use purification process for the production of a monoclonal antibody produced in a PER.C6 human cell line. Biotechnol. J. 6(1), 56-65 (2011).

51 Viswanathan S, Keating A, Deans R et al. Soliciting strategies for developing cell-based reference materials to advance mesenchymal stromal cell research and clinical translation. Stem Cells Dev. 23(11), 1157-1167 (2014).

52 Hampson B, Rowley J, Venturi N. Manufacturing patientspecific cell therapy products. BioPro Int. 6(8), 60-72 (2008).

53 Mason C, Manzotti E. The translation cycle: round and round in cycles is the only way forward for regenerative medicine. Regen. Med. 5(2), 153-155 (2010).

54 Hare JM, Traverse JH, Henry TD et al. A randomized, double-blind, placebo-controlled, dose-escalation study of intravenous adult human mesenchymal stem cells (prochymal) after acute myocardial infarction. J. Am. Coll. Cardiol. 54(24), 2277-2286 (2009).

55 Wu J, Rostami MR, Cadavid Olaya DP, Tzanakakis ES Oxygen transport and stem cell aggregation in stirredsuspension bioreactor cultures. PLoS ONE 9(7), e102486 (2014).

56 Prado-Lopez S, Conesa A, Armiñán A et al. Hypoxia promotes efficient differentiation of human embryonic stem cells to functional endothelium. Stem Cells 28(3), 407-418 (2010).

57 Joeris K, Frerichs JG, Konstantinov K, Scheper T. In-situ microscopy: online process monitoring of mammalian cell cultures. Cytotechnology 38(1-3), 129-134 (2002).

58 Trummer E, Fauland K, Seidinger $\mathrm{S}$ et al. Process parameter shifting: part I. Effect of DOT, $\mathrm{pH}$, and temperature on the performance of Epo-Fc expressing $\mathrm{CHO}$ cells cultivated in controlled batch bioreactors. Biotechnol. Bioeng. 94(6), 1033-1044 (2006).

59 Butler M. Animal cell cultures: recent achievements and perspectives in the production of biopharmaceuticals. Appl. Microbiol. Biotechnol. 68(3), 283-291 (2005).

60 Vrábel P, Van Der Lans RGJM, Luyben KCaM, Boon L, Nienow AW. Mixing in large-scale vessels stirred with multiple radial or radial and axial up-pumping impellers: modelling and measurements. Chem. Eng. Sci. 55(23), 5881-5896 (2000).

61 Langheinrich C, Nienow AW, Eddleston T et al. Oxygen transfer in stirred bioreactors under animal cell culture conditions. Food Biopro. Proc. 80(1), 39-44 (2002).

62 Nienow AW. Reactor engineering in large scale animal cell culture. Cytotechnology 50(1-3), 9-33 (2006).

-. Key paper addressing the issues associated with large scale engineering of suspension bioreactors.

63 Guidance for Industry. PAT - a framework for innovative pharmaceutical development, manufacturing and quality assurance (2004). www.fda.gov/downloads/Drugs/Guidances/ucm070305.pdf 
64 Ganguly J, Vogel G. Process analytical technology (PAT) and scalable automation for bioprocess control and monitoring - a case study. Pharmaceutical Eng. 26(1), 1-9 (2006).

65 Merten OW, Dante J, Noguiez-Hellin P, Laune S, Klatzmann D, Salzmann JL. New process for cell detachment: use of heparin. In: Animal Cell Technology. Carrondo MT, Griffiths B, Moreira JP (Eds). Springer, Netherlands (1997).

66 Kedong S, Xiubo F, Tianqing $\mathrm{L}$ et al. Simultaneous expansion and harvest of hematopoietic stem cells and mesenchymal stem cells derived from umbilical cord blood. J. Mater. Sci. Mater. Med. 21(12), 3183-3193 (2010).

67 Abraham EJ, Slater KA, Sanyal S, Linehan K, Flaherty PM, Qian S. Scale-up of mammalian cell culture using a new multilayered flask. J. Vis. Exp. 58, pii:3418 (2011).

68 Nienow AW, Rafiq QA, Coopman K, Hewitt CJ. A potentially scalable method for the harvesting of hMSCs from microcarriers. Bio. Eng. J. 85(0), 79-88 (2014).

- First paper to show the use of intense agitation for cell detachment as a scale up technique with a sound theoretical base.

69 Mikola M, Seto J, Amanullah A. Evaluation of a novel Wave Bioreactor ${ }^{\circledR}$ cellbag for aerobic yeast cultivation. Biopro. Biosys. Eng. 30(4), 231-241 (2007).

70 Singh V. Disposable bioreactor for cell culture using waveinduced agitation. Cytotechnology 30 (1-3), 149-158 (1999).

71 Kim J, Seong J, Lee B, Hashimura Y, Groux D, Oh D. Evaluation of a novel pneumatic bioreactor system for culture of recombinant Chinese hamster ovary cells. Biotech. Biopro. Eng. 18(4), 801-807 (2013).

72 Lee B, Fang D, Croughan M, Carrondo M, Paik S-H. Characterization of novel pneumatic mixing for single-use bioreactor application. BMC Proc. 5(8), 1-2 (2011).

73 Rowley J, Abraham E, Campbell A, Brandwein H, Oh S. Meeting lot-size challenges of manufacturing adherent cells for therapy. BioPro Int. 10(3), 16-22 (2012).
74 Rafiq QA, Brosnan KM, Coopman K, Nienow AW, Hewitt CJ. Culture of human mesenchymal stem cells on microcarriers in a 51 stirred-tank bioreactor. Biotech Lett. 35(8), 1233-1245 (2013).

- $\quad$ First published report of large scale microcarrier expansion and harvest of hMSCs, demonstrating the feasibility of stirred reactors for cell-based therapy production.

75 Sieblist C, Hägeholz O, Aehle M, Jenzsch M, Pohlscheidt M, Lübbert A. Insights into large-scale cell-culture reactors: II. Gas-phase mixing and CO2 stripping. Biotech. J. 6(12), 1547-1556 (2011).

76 Oh SKW, Chen AK, Mok Y et al. Long-term microcarrier suspension cultures of human embryonic stem cells. Stem Cell Res. 2(3), 219-230 (2009).

77 Kehoe DE, Jing D, Lock LT, Tzanakakis ES. Scalable stirred-suspension bioreactor culture of human pluripotent stem cells. Tissue Eng. Part A 16(2), 405-421 (2010).

78 Nienow AW, Rielly CD, Brosnan K et al. The physical characterisation of a microscale parallel bioreactor platform with an industrial $\mathrm{CHO}$ cell line expressing an $\operatorname{IgG} 4$. Biochem. Eng. J. 76, 25-36 (2013).

79 Antwiler GD, Windmiller DA, Givens M. Method of reseeding adherent cells grown in a hollow fiber bioreactor system. US8691565 B2 (US 13/100,881) (2014).

80 Kasuto H, Drori-Carmi N, Zohar B. Methods and systems for harvesting cells. (14/009952) (2014).

81 Zeikus G. Pneumatic bioreactor. US7628528 B2 (US 11/258,742) (2009). 